\title{
Максимова Н.И. \\ К вопросу изучения учебного предмета «Родной язык» в системе общего образования
}

ГБУ ДПО ЧИППКРО

doi: 10.18411/trnio-09-2021-50

(Россия, Челябинск)

\begin{abstract}
Аннотация
В статье рассматриваются вопросы преподавания учебного предмета «Родной язык» в историческом аспекте. Представлены этапы развития учебного предмета в образовании России. Рассмотрены цели и задачи учебного предмета, взаимосвясь учебного предмета и общественных отношений. Показана роль изучения «родного языка» в формировании самосознания.
\end{abstract}

Ключевые слова: учебный предмет «Родной язык», национальное своеобразие, языковая политика, этнография.

\section{Abstract}

The article deals with the issues of teaching the subject "Native language" in the historical aspect. The stages of the development of the educational subject in the education of Russia are presented. The goals and objectives of the educational subject, the relationship of the educational subject and public relations are considered. The role of studying the "Native language" in the formation of self-consciousness is shown.

Keywords: academic subject "Native language", national identity, language policy, ethnography.

«Всякий мыслящий гражданин, желающий знать и понимать истинные нужды и потребности своей родины, должен прежде всего ознакомиться с теми народностями, которые входят в состав ее населения. Это ознакомление вместе с изучением законов своей собственной страны должно быть поставлено во главу угла, на самый первый план, во всякой школе. Без этого знания нет гражданина, а лишь один бесправный обыватель» [2]. Эти слова автора из предисловия к книге очень точно определяют основные цели новой предметной области «Родной язык. Родная литература», вошедшей в общеобразовательную систему в 2017 г.:

- $\quad$ воспитание гражданина и патриота;

- $\quad$ формирование познавательного интереса, любви, уважительного отношения к русскому языку, а через него - к родной культуре;

- осознание национального своеобразия русского языка;

- воспитание ответственного отношения к сохранению и развитию родного языка;

- воспитание уважительного отношения к культурам и языкам народов России;

- овладение культурой межнационального общения.

Ю. В. Гутрова подчеркивает, что «в настоящее время принципиально важным, с точки зрения обозначенных целей образования, становится использование на уроках формы организации учебной деятельности, развернутой в атмосфере коллективного размышления, в ситуации дискуссии и совместных поисков, когда обучающиеся обсуждают разные варианты решения проблемы. В основе обучения заложено диалоговое общение как между учителем и обучающимися, так и среди школьников. Постепенно происходит интериоризация этих коллективных действий, превращение в индивидуальное решение учебных задач»[1].

Очевидно, что только с помощью языка и специально организованных форм обучения формируется самосознание обучающихся, их менталитет, национальный характер, образ жизни, традиции, обычаи, мораль, система ценностей, мироощущение, видение мира. 
Нельзя не отметить, что на развитие языка оказывают влияние разные обстоятельства: и объективные, и субъективные. Россия на протяжении всей истории придерживалась разных моделей языковой политики, что находило отражение и в системе образования.

В Россия сформированы традиции образования на разных языках её народов. Роль школьной системы в многонациональном, многоэтничном и поликультурном государстве не только как института просвещения, но и как инструмента языковой и духовной интеграции народов была осознана ещё в 60-е г2. XVIII в. В середине XIX в. был принят документ, регламентирующий вопросы обучения инородцев - «Правила о мерах к образованию населяющих Россию инородцев», а в 1913 г. разработаны «Правила о начальных училищах для инородцев».

А в XX столетии русский язык испытал значительные преобразования: с 1917 по 1935 гг. декларировалось равенство всех народов и поддерживалось просвещение на разных языках. Известная «Декларация прав народов России» провозглашала право получать образование на родном языке. Как известно, 1932 год стал пиком обучения школьников на родном языке - в советских начальных и средних школах преподавание велось на 104 языках, в том числе и на некоторых мировых (в РСФСР насчитывалось 414 школ с преподаванием на немецком языке, на Украине - 628 немецких школ, на Дальнем Востоке (в Хабаровске, Никольск-Уссурийске, Владивостоке) действовали более 20 китайских школ и одни китайский педагогический техникум, а всего в учебных заведениях Дальневосточного края обучалось около четырёх тысяч детей китайских мигрантов и т. д.). В этот период начали готовить национальные педагогические кадры, писать учебники на национальных языках, разрабатывать алфавиты для языков, не имевших своих письменностей. В 19391940 гг. был взят курс на двуязычное образование и процесс русификации. В 1938 г. Совнарком СССР принял Декрет «Об обязательном обучении русскому языку в школах национальных республик и областей», следовательно, русский язык стал обязательным предметом во всех школах страны. Постепенно происходил отказ от принципа «школа на родном языке» и переход основной части национальных школ на русский язык обучения...

Закон «Об образовании» 1959 г., в котором содержалось положение о добровольном выборе родителями языка обучения их детей, привел к потере национально-русского двуязычия и к переходу обучения на русский язык. К середине 1980-х гг. национальная школа практически растворилась в общеобразовательном пространстве. В новой России 1990-х были приняты новые документы - закон «О национально-культурной автономии», «О гарантиях прав коренных малочисленных народов РФ», Концепции государственной национальной политики, то есть этническая политика в значительной степени определялась как политика мультикультурализма. Концепт «многонационального народа», принцип равенства представителей российских национальностей и поддержка культур были заложены в Конституции 1993 г. (после распада СССР). Поддержка полиэтничности проводилась и в образовательной политике России.

Россия XXI в. - это страна с доминирующей русскоязычной культурой. Русским языком владеют практически все жители нашей страны. Представители нерусских национальностей, как правило, двуязычны (либо владеют русским языком лучше, чем своим «этническим»). Во многих регионах обучение детей разных национальностей ведется на русском языке (по всей стране русский язык является обязательным школьным предметом). Можно заметить, что многие граждане постсоветских государств в настоящее время выбирают местом жительства Россию.

Нельзя не согласится со словами академика, научного руководителя Института этнологии и антропологии РАН В. А. Тишкова, что «...по всем международным стандартам национальный язык в Российской Федерации - это русский язык, ибо национальный язык это язык нации как согражданства. Там, где этот язык или языки объявлены государственными, государственный и национальный - это синонимы» [4]. Такое совпадение с этническим языком русского народа обусловлено историей нашего государства. Демографическая ситуация в период XIX - XX столетий доказывает, что русские - самая большая группа населения, проживающая на территории России. Большая 
часть нерусского населения России XXI в. имеют в качестве «материнского» языка не язык своей национальности, а русский язык.

Согласно Всероссийской переписи населения 2010 г. в стране зафиксировано 277 языков. По оценкам экспертов в реальности используется порядка 150 языков. Масштаб языкового многообразия России беспрецедентен: 100 языков - письменные, в том числе на 59 создаются литературные произведения, издаются книги и журналы. При этом русским языком, обладающим статусом государственного на всей территории России, владеет 98,2 \% населения. Кроме того, 23 \% владеет еще 38 языками. Остальные 114 языков распространены лишь среди $1 \%$ населения. Таким образом, наблюдается, с одной стороны, языковое единство и языковое доминирование русского языка, с другой - большое языковое и культурное разнообразие.

Конституцией РФ закреплен статус языков, функционирующих на территории страны: государственный язык РФ, республиканские государственные языки, родные языки. Государственным языком России на всей ее территории является русский язык [3, ст. 68, п. 1]. Статусом республиканских государственных языков наделены 25 языков в 19 республиках. Их статус закреплен Конституцией РФ, конституциями республик и республиканскими законами о языках. Кроме того, некоторые языки в ряде республик не имеют статуса государственного, но обладают аналогичными функциями. Например, 14 языков с наибольшим количеством носителей в Дагестане, в Республике Карелия. В ряде республик РФ (Хакасия, Адыгея, Коми, Бурятия, Удмуртия, Башкирия, Алтай, Мордовия, Марий Эл, Саха (Якутия)) титульные национальности составляют численное меньшинство среди местного населения, что, естественно, влияет на языковую ситуацию в этих республиках.

Современное преподавание русского языка в школах Российской Федерации вступило в новый организационный этап в 2017 г. Термины «государственный русский язык» и «родной язык (русский)» получили новую нормативную организацию.

Закон об изучении родных языков, принятый летом 2018 г., был призван стабилизировать ситуацию, которая возникла в связи с введением понятий «родной язык» и «Государственный русский язык» в учебные планы всех типов школ РФ. «Предмет «Родной язык» в школе нужен, но не так, «чтобы для русских - это русский, для татар — татарский, для мордвина - мокшанский или эрзянский. Большинство российских татар и мордвы живет за пределами «своих» республик, не говорит и даже не знает языка «своей» национальности. Для этой части населения русский язык является не «техническим языком для формальных коммуникаций», а их основным, а зачастую - единственным языком, который они знают и которым пользуются» [4,c.34].

Приказами Минобрнауки России от 31 декабря 2015 г. были внесены изменения в федеральные государственные образовательные стандарты. В частности, произошло разграничение предметной области «Филология» на 3 предметные области: «Русский язык. Литература», «Родной язык. Родная литература», «Иностранный язык. Второй иностранный язык».

Приказом № 1576 во ФГОС НОО (утвержденный приказом № 373 от 6 октября 2009 г.) добавлен пункт 12.2, включающий предметные результаты по «Родному языку» и «Литературному чтению на родном языке». Приказом № 1577 во ФГОС ООО (утвержденный приказом № 1897 от 17 декабря 2010 г.) добавлен пункт 11.2, включающий предметные результаты по «Родному языку и родной литературе». Приказом № 1578 во ФГОС СОО (утвержденный приказом № 413 от 17 мая 2012 г.) добавлен пункт 9.2, включающий предметные результаты по «Родному языку и родной литературе на базовом и углубленном уровнях». Предметная область «Родной язык. Родная литература» не осталась без внимания и в ФГОС НОО 2021 г (утверженный приказом Министерства Просвещения № 286 от 31 мая 2021 г.) и в ФГОС ООО 2021 г (утверженный приказом Министерства Просвещения № 287 от 31 мая 2021 г.).

Учебный предмет «Родной язык» вводился в практику преподавания поэтапно на протяжении нескольких лет. На всероссийских и региональных семинарах обсуждались 
вопросы преподавания предметов «Родной язык» и «Литературное чтение на родном языке», «Родной язык» и «Родная литература». На сегодняшний день учебные предметы «Родной язык» и «Литературное чтение на родном языке», «Родной язык» и «Родная литература» занимают по праву своё место в расписании образовательных организаций.

Для Челябинской области, как и для России в целом, характерно сочетание полиэтничности со значительным преобладанием русского населения.

На гистограмме, приведеной ниже, показано распределение школ с преподаванием родных языков (русского, татарского, башкирского) в Челябинской области.

\section{Родные языки с системе обещего образования Челябинской области}

Количество школ, в которых преподается родной татарский язык

Количество школ, в которых преподается родной башкирский язык

Количество школ, в которых преподается родной русский язык

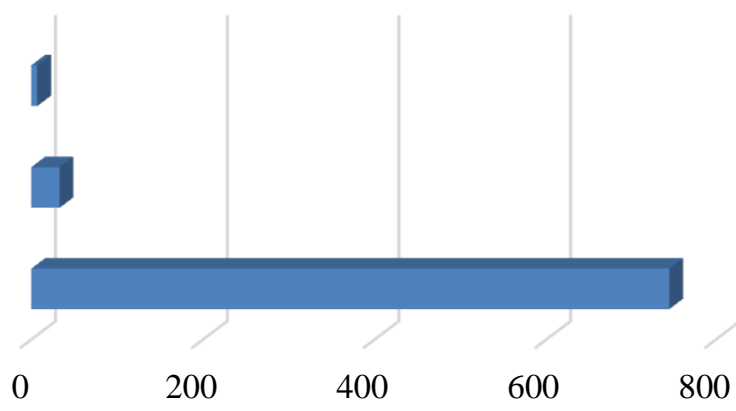

\begin{tabular}{|c|c|c|}
\hline & $\begin{array}{c}\text { Количество школ, в которых } \\
\text { преподается родной русский } \\
\text { язык }\end{array}$ & $\begin{array}{c}\text { Количество школ, в которых } \\
\text { преподается родной } \\
\text { башкирский язык }\end{array}$ \\
\hline - Ряд1 & 745 & 33 \\
\hline
\end{tabular}

Количество школ, в которых преподается родной татарский язык 7

Гистограмма 1

Анализ системы преподавания родных языков в Челябинской области позволил выявить ряд комплексных проблем: отсутствие единства принципов и подходов, действий в развитии преподавания родных языков как на уровне субъекта Российской Федерации, так и в каждой образовательной организации. Недостаточное обеспечение учебно-методическими пособиями и учебниками, а также отсутствие преемственности преподавания родных языков между уровнями образования.

Таким образом, отметим, что проблемы, связанные с низким уровнем вовлечения родителей (законных представителей) обучающихся в процессы сохранения и изучения родных языков, остаются открытыми и свидетельствуют о недароботке в области преподавания родных языков. Низкий уровень мотивации семьи в вопросах изучения родных языков, подтверждает размышления о том, что недостаточно ведется просветительская, разъяснительная работа с родителями (законными представителями) обучающихся в образовательных организациях не только в Челябинской области, но и на всей территории России.

$$
* * *
$$

1. Гутрова, Ю.В. Дифференциорованно-групповая форма работы как средство повышения качества обучения. Диссертация кандидата педагогических наук: 13.00.01. - Челябинск, 2002. - 196 с.: ил. Общая педагогика, история педагогики и образования.

2. Инфантьев, П.П. Этнографические рассказы: Из жизни татар, киргизов, калмыков, башкир, вогулов и самоедов., СПб., 1909. - 262 с.

3. «Конституция Российской Федерации» (принята всенародным голосованием 12.12.1993 с изменениями, одобренными в ходе общероссийского голосования 01.07.2020)

4. Смерть языка - смерть народа? Языковые ситуации и языковые права в России и сопредельных государствах / С. В. Соколовский, Е. И. Филиппова, И. Л. Бабич и др.; Отв. редакторы Е. И. Филиппова и С. В. Соколовский. - М.: Институт этнологии и антропологии им. Н. Н. Миклухо-Маклая РАН, Горячая линия - Телеком, 2019. - 260 с. 